\title{
GAMBARAN KADAR GULA DARAH PUASA PADA LAKI- LAKI USIA 40-59 TAHUN
}

\author{
${ }^{1}$ Hindri Djakani \\ ${ }^{2}$ Theresia V. Masinem \\ ${ }^{2}$ Yanti M. Mewo
}

\author{
${ }^{1}$ Kandidat SKRIPSI Fakultas Kedokteran Universitas Sam Ratulangi Manado \\ ${ }^{2}$ Bagian Biokimia Fakultas Kedokteran Universitas Sam Ratulangi Manado \\ Email:paai_manado@yahoo.com
}

\begin{abstract}
Glucose is a universal fuel of human cells and functions as a source of carbon for the synthesis of most of other compounds. Blood glucose level is used as a parameter of the successful metabolism in the body. In certain circumstances with respect to the blood glucose levels in the body, hypoglycemia or hyperglycemia can occur. The aim of this study was to find out a profile of fasting blood sugar levels (FBS) in males aged 40-59. The method used was consecutive sampling with the number of subjects was as many as 46 males who lived in Malalayang Manado. Of the 46 subjects, there were three who did not meet the criteria. The results of this study showed that four subjects had low levels of FBS, four subjects had high FBS, and 35 subjects had normal FBS. Conclusion: In this study most males aged 40-59 years who lived in Malalayang Manado had normal fasting blood sugar levels.
\end{abstract}

Key words: males, fasting blood sugar

\begin{abstract}
Abstrak: Glukosa merupakan bahan bakar universal bagi sel-sel tubuh manusia dan merupakan sumber karbon untuk sintesis sebagian besar senyawa lainnya. Kadar glukosa dipergunakan sebagai parameter keberhasilan metabolisme dalam tubuh. Dalam keadaan tertentu sehubungan dengan kadar glukosa di dalam tubuh, dapat terjadi hipoglikemia atau hiperglikemia. Penelitian ini bertujuan untuk mengetahui gambaran kadar gula darah puasa (GDP) pada laki-laki berusia 40-59 tahun. Metode yang digunakan ialah consecutive sampling dengan jumlah subjek sebanyak 46 orang yang berdomisili di Kecamatan Malalayang Manado. Dari 46 subjek, terdapat tiga orang yang tidak memenuhi criteria. Hasil penelitian memeperlihatkan empat subjek memiliki kadar GDP rendah, empat subjek memiliki kadar GDP tinggi, dan 35 subjek memiliki GDP normal. Simpulan: Dalam penelitian ini sebagian besar laki-laki berusia 40-59 tahun yang berdomisili di Malalayang memiliki kadar gula darah puasa normal.
\end{abstract}

Kata kunci: laki-laki, kadar gula darah puasa

Glukosa merupakan bahan bakar universal bagi sel-sel tubuh manusia dan berfungsi sebagai sumber karbon untuk sintesis sebagian besar senyawa lainnya. Semua jenis sel manusia menggunakan glukosa untuk memperoleh energi ${ }^{1}$.

Umumnya makanan mengandung tiga unsur yaitu karbohidrat, lemak, dan protein. Dari ketiga unsur tersebut yang merupakan sumber energi utama ialah karbohidrat. Karbohidrat ialah senyawa organik dengan fungsi utama sebagai sumber energi bagi kebutuhan sel-sel dan jaringan tubuh. Peran utama karbohidrat di dalam tubuh ialah menyediakan glukosa bagi sel-sel tubuh, yang kemudian diubah menjadi energi. Glukosa merupakan jenis karbohidrat terpenting bagi tubuh manusia. ${ }^{2}$ Karbo- 
hidrat dibutuhkan oleh tubuh sebagai sumber utama tenaga untuk bergerak, membentuk glukosa otot sebagai energi cadangan tubuh, dan juga membentuk protein dan lemak. ${ }^{3}$

Kebanyakan karbohidrat dalam makanan diserap ke dalam aliran darah sebagai glukosa, galaktosa, serta fruktosa, dan akan diubah menjadi glukosa di dalam hati. ${ }^{4}$ Glukosa yang beredar dalam aliran darah menyediakan 50-75\% dari kebutuhan energy total. ${ }^{5}$

\section{GLUKOSA DARAH}

Glukosa darah atau sering disebut gula darah adalah salah satu gula monosakarida dan salah satu sumber karbon terpenting yang digunakan sebagai sumber energi hewan dan tumbuhan. ${ }^{6}$ Umumnya kadar glukosa darah bertahan pada batas-batas yang sempit sepanjang hari, yaitu 4-8 $\mathrm{mmol} / \mathrm{L} \quad(70-150 \mathrm{mg} / \mathrm{dL})$. Kadar ini meningkat setelah makan dan biasanya berada pada kadar terendah pada pagi hari sebelum makan. ${ }^{6}$

Glukosa juga merupakan prekursor pokok bagi senyawa non-karbohidrat. Glukosa dapat diubah menjadi lemak termasuk asam lemak, kolesterol, dan hormon steroid, asam amino, dan asam nukleat. Dalam tubuh manusia hanya senyawasenyawa yang disintesis dari vitamin, asam amino non-esensial, dan asam lemak esensial yang tidak dapat disintesis dari glukosa. ${ }^{2}$

\section{SUMBER GLUKOSA DARAH}

\section{Katabolisme dan absorpsi karbohidrat dalam saluran pencernaan.}

Karbohidrat dalam diet umumnya terdapat dalam bentuk zat pati, laktosa, sukrosa, dan selulosa. Di rongga mulut, enzim amilase saliva bekerja pada zat pati secara acak menghasilkan maltosa, beberapa glukosa, dan unit-unit molekul pati yang kecil atau dekstrin. Di dalam lambung, kerja amilase terhenti karena tingkat keasaman yang tinggi (HCI). Di dalam usus halus, $\mathrm{pH}$ bolus makanan menjadi alkali oleh sekresi pankreas. Pencernaan dekstrin pati dilanjutkan oleh kerja enzim $\alpha$ amilase pankreas yang serupa dengan enzim dari saliva. Bila kerja $\alpha$ amilase menghidrolisis zat pati sempurna, lumen usus halus akan mengandung glukosa, maltosa, isomaltosa, serta laktosa dan sukrosa dari diet. Selulosa yang dimakan ialah polisakarida yang tidak dapat dicernakan pada manusia karena enzim yang menghidrolisisnya tidak dibentuk. Disakarida (maltosa, isomaltosa, laktosa) akan dihidrolisis pada brush border mukosa usus halus. ${ }^{7}$.

\section{Glikogenolisis}

Glikogen merupakan karbohidrat simpanan utama pada hewan, setara dengan pati atau kanji pada tumbuhan. Glikogen adalah polimer bercabang $\alpha$-D-glukosa. Zat ini terutama ditemukan di hati dan otot. Meskipun kandungan glikogen hati lebih tinggi dari pada kandungan glikogen otot, namun karena massa otot tubuh total jauh lebih besar dari pada massa hati, sekitar tiga-perempat glikogen tubuh total berada di otot. Glikogen otot merupakan sumber glukosa yang cepat digunakan untuk glikolisis di dalam otot itu sendiri. Glikogen hati berfungsi untuk menyimpan dan mengirim glukosa untuk mempertahankan kadar glukosa darah di antara waktu makan dan setelah 12-18 jam berpuasa. $^{8}$

Deretan reaksi hidrolisis glikogen menjadi glukosa merupakan proses katabolisme cadangan sumber energi. Enzim utama yaitu glikogen fosforilase, memecah ikatan 1-4 glikogen. Selanjutnya, enzim transferase akan memindahkan tiga residu glukosil dari cabang terluar ke cabang lain. Pemindahan ini menyebabkan titik cabang 1-6 terpapar. Ikatan 1-6 akan diputus oleh debranching enzyme (amino 1-6 glukosidase). Transferase dan debranching enzyme akan mengubah struktur bercabang glikogen menjadi lurus, yang membuka jalan untuk pemecahan selanjutnya oleh fosforilase dan menghasilkan glukosa 1 
fosfat. ${ }^{7}$ Glukosa 1 fosfat secepatnya diubah menjadi glukosa 6 fosfat di hepar dan ginjal. Glukosa 6 fosfatase mengeluarkan fosfat dari Glukosa 6 fosfat sehingga glukosa berdifusi dari sel ke darah yang berakibat kenaikan gula darah. ${ }^{7}$

\section{Glukoneogenesis}

Pada dasarnya glukoneogenesis ialah sintesis glukosa dari senyawa yang bukan karbohidrat, misalnya asam laktat dan beberapa asam amino. Proses glukoneogenesis berlangsung terutama di hati. Asam laktat yang terjadi pada proses glikolisasi dapat dibawa oleh darah ke hati, dan diubah menjadi glukosa kembali melalui serangkaian reaksi dalam proses yaitu glukoneogenesis. $^{2}$

Glukoneogenesis terkait dengan banyak enzim yang sama dengan glikolisis, tetapi glukoneogenesis bukan kebalikan dari proses glikolisis karena terdapat tiga tahap reaksi dalam glikolisis yang tidak reversibel, artinya perlu enzim lain untuk kebalikannya, yaitu glukokinase, fosfofruktokinase, dan piruvatkinase. $^{2}$

Glukagon merangsang glukoneogenesis dengan merangsang enzim-enzim tersebut terutama fosfoenol piruvat karboksikinase. Biosintesis enzim-enzim tersebut juga dipengaruhi oleh insulin dan hormon glukokortikoid. Defek enzim glukoneogenesis menimbulkan hipoglikemia dan asidosis laktat. Enam ikatan fosfat berenergi tinggi digunakan untuk pembentukan glukosa dalam reaksi ini. ${ }^{7}$

Hubungan antara glukoneogenesis dan jalur glikolitik diperlihatkan pada Gambar 3. Setelah transminasi atau deaminasi, asam-asam amino glukogenik menghasilkan piruvat atau zat-zat antara siklus asam sitrat. Oleh karena itu, reaksi ini dapat menyebabkan perubahan laktat maupun asam amino glukogenik menjadi glukosa dan glikogen. ${ }^{10}$

\section{HORMON YANG MEMPENGARUHI GLUKOSA DARAH}

Glukagon dan epinefrin merupakan hormon yang berperan meningkatkan kadar glukosa darah, menghambat glikolisis, dan merangsang glukoneogenesis di hati dengan meningkatkan konsentrasi cAMP. Hal ini akan mengaktifkan protein kinase tergantung piruvat kinase. Keduanya juga mempengaruhi konsentrasi fruktosa 2,6bisfosfat sehingga mempengaruhi glikolisis dan glukoneogenesis. ${ }^{10}$

Kelenjar hipofisis anterior menyekresi hormon-hormon yang cenderung meningkatkan kadar glukosa darah sehingga melawan kerja insulin; hormon-hormon ini ialah hormon pertumbuhan. ${ }^{10}$ Sekresi hormon pertumbuhan dirangsang oleh hipoglikemia, dan hormon ini menurunkan penyerapan glukosa di jaringan otot.

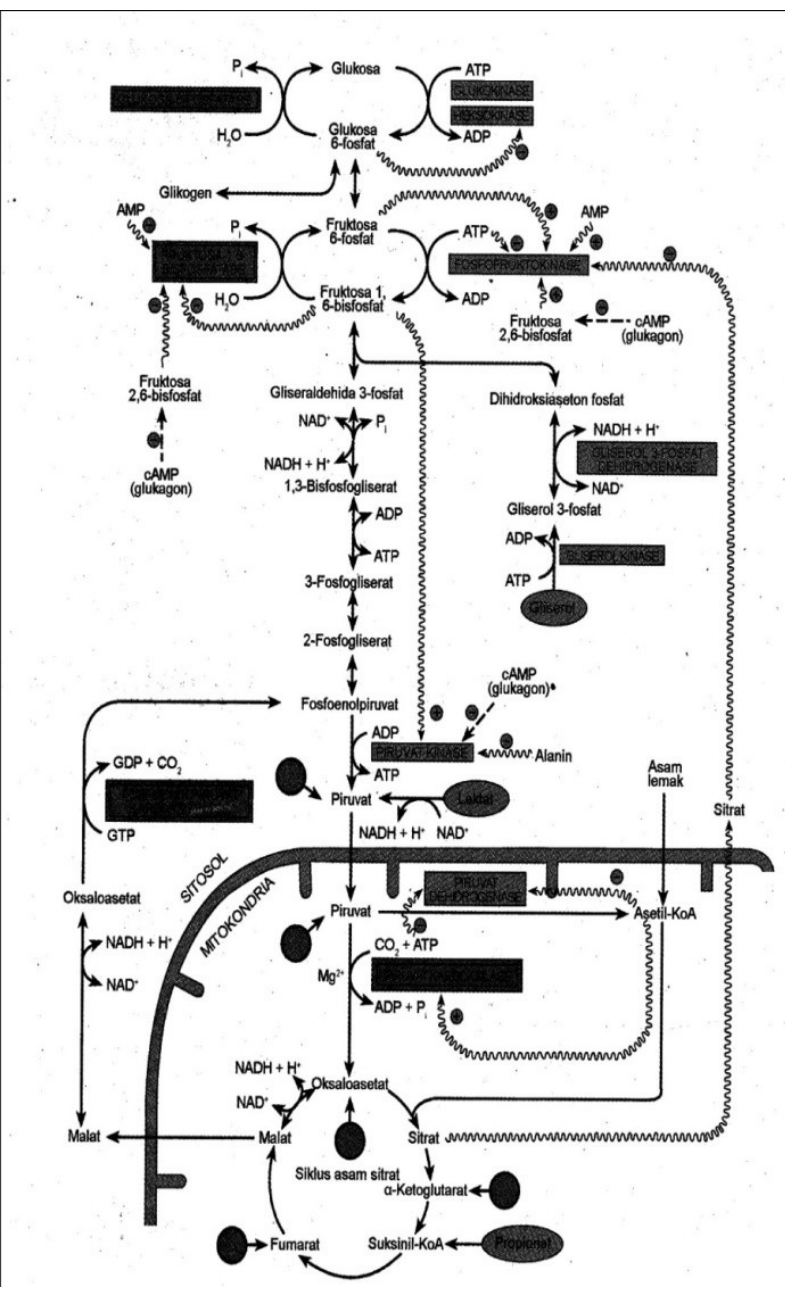

Gambar 3. Jalur reaksi glukoneogenesis. ${ }^{10}$ 
Glukokortikoid disekresikan oleh korteks adrenal dan juga disintesis di jaringan adiposa tanpa diregulasi. Hormon ini bekerja dengan meningkatkan glukoneogenesis melalui peningkatan katabolisme asam amino di hati akibat induksi pada aminotransferase (dan enzim lain, misalnya triptofan dioksigenase) serta enzim-enzim kunci pada glukoneogenesis. Hal ini menjelaskan mengapa resistensi insulin sering dijumpai pada obesitas. ${ }^{10}$

\section{METODOLOGI PENELITIAN}

Penelitian ini bersifat deskriptif dengan pendekatan survei dan berlangsung sekitar satu bulan (Desember 2011). Lokasi penelitian di Kecamatan Malalayang, Manado, Sulawesi Utara. Pengambilan sampel darah dilakukan di Laboratorium Klinik Pro-Kita, Malalayang, Manado. Populasi penelitian laki-laki berusia 40-59 tahun. Pengambilan sampel dilakukan dengan metode consecutive sampling dan diperoleh sampel 43 orang.

\section{Kriteria pemilihan sampel}

Kriteria inklusi: laki-laki berusia 40-59 tahun, bersedia menjadi subyek penelitian, dan sehat pada saat diperiksa.

Kriteria esklusi: sedang dalam program diet, pemakaian obat-obatan yang mempengaruhi kadar glukosa, dan seorang atlit.

\section{Variabel penelitian}

Variabel bebas ialah laki-laki berusia 40-59 tahun, sedangkan variabel tergantung ialah kadar gula darah puasa.

\section{Definisi operasional}

1. Usia subyek berdasarkan ulang tahun terakhir.

2. Kadar gula darah puasa (GDP) diambil dari darah vena setelah subyek berpuasa selama 12 jam. GDP rendah $<65$ $\mathrm{mg} / \mathrm{dL}$; normal $65-110 \mathrm{mg} / \mathrm{dL}$; dan tinggi $>110 \mathrm{mg} / \mathrm{dL}$.

\section{HASIL}

Subyek penelitian berjumlah 43 lakilaki berusia 40-59 tahun yang berdomisili di Kecamatan Malalayang, Manado, Sulawesi Utara. Rentang usia yang dipakai 40-59 tahun dengan rerata 47 (Tabel 1).

Tabel 1. Karakteristik subyek berdasarkan usia.

\begin{tabular}{cllc}
\hline Usia & $\mathbf{N}$ & $\mathbf{( \% )}$ & Mean \pm SD \\
\hline $40-49$ & 25 & 58,14 & $47 \pm 36$ \\
$50-59$ & 18 & 41,86 & \\
\hline
\end{tabular}

Data pekerjaan subyek didominasi oleh swasta, dan lainnya ialah nelayan, PNS, polisi, dan pensiunan (Tabel 2).

Tabel 2. Karakteristik subyek berdasarkan pekerjaan.

\begin{tabular}{ccc}
\hline Pekerjaan & n & $\mathbf{( \% )}$ \\
\hline Swasta & 24 & 53,48 \\
Nelayan & 8 & 18,60 \\
PNS & 5 & 11,65 \\
Polisi & 4 & 9,30 \\
Pensiunan & 3 & 6,97 \\
\hline
\end{tabular}

Berdasarkan hasil pengukuran IMT, sebagian besar subyek penelitian memiliki IMT 18,5-22,9 yang menunjukkan status gizi normal (Tabel 3).

Tabel 3. Distribusi subyek menurut kategori status gizi berdasarkan Indeks Massa Tubuh (IMT) $\mathrm{kg} / \mathrm{m}^{2}$.

\begin{tabular}{lcc}
\hline $\begin{array}{c}\text { Kategori status gizi } \\
\text { berdasarkan IMT } \\
\left(\mathbf{k g} / \mathbf{m}^{2}\right)\end{array}$ & $\mathbf{n}$ & $\mathbf{\%}$ \\
\hline Kurang $\leq 18,5$ & 0 & - \\
Normal $(18,5-22,9)$ & 22 & 51,16 \\
Overweight $(23,0-24,9)$ & 2 & 4,65 \\
Obesitas 1 $(25,0-29,9)$ & 13 & 30,24 \\
Obesitas 2 $(\geq 30)$ & 6 & 13,95 \\
\hline
\end{tabular}

Data kadar gula darah puasa subyek penelitian menunjukkan bahwa sebagian besar subyek baik dengan IMT normal maupun lebih memilki kadar GDP normal (Tabel 4). 
Tabel 4. Persentase subyek menurut kadar GDP (mg/dL) dan IMT $\left(\mathrm{kg} / \mathrm{m}^{2}\right)$.

\begin{tabular}{lcccc}
\hline \multicolumn{1}{c}{$\begin{array}{c}\text { Kadar GDP } \\
(\mathbf{m g} / \mathbf{d L})\end{array}$} & \multicolumn{2}{c}{ IMT } & \multicolumn{2}{c}{ IMT } \\
& $\mathbf{( 1 8 , 5 - 2 2 , 9 )}$ & \multicolumn{2}{c}{$(\geq \mathbf{2 3})$} \\
\cline { 2 - 5 } & $\mathbf{n}$ & $\mathbf{\%}$ & $\mathbf{n}$ & $\mathbf{\%}$ \\
\hline Rendah $<65$ & 3 & 13,63 & 1 & 4,76 \\
Normal $65-110$ & 17 & 77,28 & 18 & 85,72 \\
Tinggi $>110$ & 2 & 9,09 & 2 & 9,52 \\
\hline Total & 22 & 100 & 21 & 100 \\
\hline
\end{tabular}

\section{BAHASAN}

Pada penelitian ini diperoleh subyek sejumlah 43 orang dengan rerata usia 47 (Tabel 1). Empat subyek (9,3\%) memiliki kadar GDP >110 mg/dL, yang memperlihatkan bahwa peningkatan kadar GDP tidak hanya terjadi pada usia tua tapi juga pada usia di bawah 50 tahun (Tabel 4).

Kecamatan Malalayang merupakan wilayah yang cukup besar dengan tingkat pengetahuan masyarakat yang cukup memadai. Meskipun lokasi penelitian berada pada daerah pantai tetapi yang bekerja sebagai nelayan hanya $18,60 \%$, sedangkan lainnya sebagai swasta, PNS, polisi, dan pensiunan (Tabel 2).

Hasil penelitian memperlihatkan bahwa sebagian besar subyek $(51,16 \%)$ memiliki status gizi normal. Hasil pemeriksaan GDP baik pada subyek dengan status gizi normal $(77,28 \%)$ maupun yang overweight dan obesitas $(85,72 \%)$ sebagian besar masih normal (Tabel 4).

Hasil yang beragam dalam penelitian ini secara tidak langsung membuktikan bahwa status gizi dan IMT normal tidak selalu disertai kadar GDP yang normal. Pola hidup sangat berperan dalam status gizi seseorang. Dengan demikian kebiasaan makan dan aktifitas fisik perlu diperhitungkan, juga faktor genetik.

\section{SIMPULAN}

Berdasarkan hasil penelitian ini dapat disimpulkan bahwa sebagian besar laki-laki berusia 40-59 tahun yang berdomisili di Kecamatan Malalayang Manado memiliki kadar gula darah puasa normal.

\section{DAFTAR PUSTAKA}

1. Marks BD, Marks DA, Smith MC. Metabolisme karbohidrat. In: Marks $\mathrm{BD}$, editor. Biokimia Kedokteran Dasar. Jakarta: EGC, 1999; p.381-462.

2. Metabolisme Karbohidrat (Glukosa) [homepage on the internet]. 2011 [update $2011 \mathrm{Jul}$; cited 2011 Nov 27]. Available from: http://artikelkedokteran.net/metabolismekarbohidrat.html.

3. Irawan AM. Karbohidrat [homepage on the Internet]. 2004 (update 2004 Des; cited 2011 Des]. Available from: www. pssplab.com.

4. Bender DA, Mayes PA. Karbohidrat yang penting secara fisiologis. In: Murray RK, Granner DK, Rodwell VW, editor. Biokimia Harper. Jakarta: EGC, 2009; p.119-27.

5. Irawan AM. Glukosa dan Metabolisme Energi [homepage on the Internet]. 2007 [cited 2011]. Available from: www.pssplab.com.

6. Indarti. Perbedaan kadar glukosa darah pada penderita diabetes melitus berdasarkan pengaturan makanan [homepage on the Internet]. 2005 [cited 2012 Januari 10]. Available from:

7. Sari IM. Reaksi-reaksi biokimia sebagai sumber glukosa darah. Jakarta : 2007.

8. Bender DA, Mayes PA. Metabolisme glikogen. Biokimia Harper (Edisi Keduapuluh tujuh). Jakarta: EGC, 2009; p.166-73.

9. Glukoneogenesis (Biokimia) [home pages the Internet]. 2002. Yogyakarta. Bagian Kardiologi FKUI/RSJHK. [update 2002 Aug; Cited 2012 Jan 10]. Available from: http://artikel kedokteran.net/glukoneogenesis.html.

10. Bender DA, Mayes PA. Glukogenesis dan kontrol gula darah. Biokimia Harper (Edisi Keduapuluh tujuh). Jakarta: EGC, 2009; p.181-3. 